\title{
The Bank of Amsterdam through the Lens of Monetary Competition
}

\author{
Stephen Quinn and William Roberds
}

\section{Working Paper 2012-14 \\ September 2012}

\begin{abstract}
In 1683 the Bank of Amsterdam introduced a form of fiat money that successfully competed with the coinage of the time. We argue that the principal motive for this monetary innovation was the uncertain value of coins circulating within the Dutch Republic. The Bank's fiat money regime persisted until the downfall of the Dutch Republic in 1795 and incorporated modern features such as gross settlement of financial obligations, open market operations, central bank repurchase agreements (the equivalent thereof), and emergency liquidity facilities.
\end{abstract}

JEL classification: E42, E58, N14

Key words: fiat money, central bank, monetary competition

This paper was prepared for the conference "The Political Economy of Monetary Innovation," held in Heidelberg, Germany, August 9-12, 2012. The authors are grateful to the conference organizers, Peter Bernholz and Roland Vaubel, as well as to conference participants for comments on an earlier draft. The views expressed here are the authors' and not necessarily those of the Federal Reserve Bank of Atlanta or the Federal Reserve System. Any remaining errors are the authors' responsibility.

Please address questions regarding content to Stephen Quinn, Department of Economics, Texas Christian University, TCU Box 298510, 2855 Main Drive, Fort Worth, TX 76129, 817-257-6234, s.quinn@tcu.edu, or William Roberds, Research Department, Federal Reserve Bank of Atlanta, 1000 Peachtree Street, N.E., Atlanta, GA 30309-4470, 404-498-8970, william.roberds@atl.frb.org.

Federal Reserve Bank of Atlanta working papers, including revised versions, are available on the Atlanta Fed's website at frbatlanta.org/pubs/WP/. Use the WebScriber Service at frbatlanta.org to receive e-mail notifications about new papers. 


\section{The Bank of Amsterdam through the Lens of Monetary Competition}

A paradoxical aspect of any modern economy is that its most sought-after asset—fiat moneymay also be its least intuitive. Fiat money, by definition, consists of only irredeemable claims: banknotes or entries in the accounts of a central bank. In concrete terms, these items appear to signify nothing. Yet fiat money has an unquestioned and unparalleled ability to quickly and irreversibly complete a transaction, be it a multimillion-dollar stock trade or a back-alley drug deal.

Why should an imaginary asset play this critical role? There are numerous economic theories of the emergence of fiat money, but these commonly fall into two broad categories (Kahn and Roberds 2009). The first group of explanations (the "Mahagonny theories" ${ }^{1}$ ) postulates that the value of fiat money arises principally from laws that compel its use. A second group of explanations (the "Peter Pan theories" ${ }^{2}$ ) argues that fiat money is universally accepted precisely because it is believed to be so.

To evaluate the applicability of these theories, this paper will briefly examine the experience of an innovative fiat money regime, introduced by the Bank of Amsterdam in the late seventeenth century and persisting until the downfall of the Dutch Republic in 1795. And while elements of the Mahagonny and Peter Pan stories are recognizable in the Amsterdam narrative, we will argue a third explanation (working name: "Icarus”) better fits the facts. That is, by moving to a fiat (or near-fiat) monetary standard, the merchant community of Amsterdam was for a time able to escape the ill effects of contemporary commodity money. Aided by the force of law and custom, imaginary money on the Bank’s ledgers succeeded because it was more reliable than the real stuff.

\footnotetext{
${ }^{1}$ The1930 Brecht/Weill opera takes place in a city where it is a crime to be caught without money.

${ }^{2}$ In J.M. Barrie's work, fairies exist only if enough people believe in them.
} 
Amsterdam's monetary system was however a delicate construct that, like Icarus' waxen wings, could be subject to sudden and catastrophic failure. The Bank collapsed in 1795 following a period of intense exploitation that ran directly counter to its founding principles. But the downfall occurred only after the Bank had helped bring prosperity to Amsterdam, in the process attaining a degree of monetary sophistication that would not be replicated until the twentieth century.

\section{Competition and Political Economy}

To describe the Bank of Amsterdam’s evolution, we begin with the Bank’s ecosystem. It was economic in that the Bank offered a ledger-money that grew into a distinct unit of account and medium of exchange. The situation was also political. The City of Amsterdam did not have its own mint, so the city used the Bank to assert monetary power. The Bank's political economy was part of a system because Bank money competed with other monies: coins, bank accounts, bills of exchange, etc. Finally, the monetary competition was strategic because governmentsponsored suppliers of money relied on legal privileges, and capitalizing on those advantages created spillovers on other suppliers.

This environment created a policy trade-off between seigniorage and monetary efficiency for each monetary institution and its controlling political authority. The classic example is of a mint that could debase its coins, within limits, to gain more revenue. Debasement increased seigniorage, but at the expense of monetary stability. For another example, a public (usually municipal) bank could lend large amounts. This created interest revenue, but it weakened the bank. Here, we will use seigniorage in a broad sense of rents accruing to the monetary institution, the controlling political authority, or even those in political favor, such as the Dutch East India Compa- 
ny. Similarly, we use monetary efficiency in a broad sense that includes stability, reliability, ease of use and cost of use.

The loose structure of the Dutch Republic created competition between monetary institutions, and the competition was strategic because the rewards from seeking revenue or seeking efficiency depended on the policies chosen by rivals. The direction of those effects, however depended on the legal privileges or the lack of same. For example, Republic ordinances said that individual provinces, e.g., Utrecht and Holland, could each mint coins that were legal tender in all provinces. If Utrecht chose to debase its coin (increase seigniorage and reduce monetary efficiency) while Holland maintained standards (reverse), then mint business migrated to Utrecht, and debased coins migrated to Holland. In this environment, Holland's strategy to keep up standards increased Utrecht's revenue, and Utrecht's strategy of debasement hurt Holland's revenue. The legal privileges assigned to the output of Dutch mints tainted monetary competition with adverse spillovers, so producing inefficient money was rewarded with more revenue. This situation was compounded by the circulation of many foreign coins within the Republic, often from neighboring jurisdictions: by the start of the seventeenth century, over one thousand different types of coin were legally recognized (Dehing and ‘t Hart 1997: 40).

In contrast, the pan-European competition among international monies occurred beyond the legal domain of any one political authority, or cluster of local authorities. Competition was not framed by legally derived spillovers, so bad money was shunned. Bills of exchange were the dominant form of international payment, and markets for bills flourished only where efficient monies were available as a settlement medium (Flandreau et al. 2009). In this environment, Amsterdam could compete by making the bank guilder a reliable, low cost money. The Bank of Amsterdam also benefited by an increase in its revenues from lending and fees. Conversely, choices 
by others to degrade the quality of their money caused business to move to Amsterdam and revenues to increase for the Bank of Amsterdam. ${ }^{3}$

Viewing the outcomes of monetary competition as a function of legal privileges lets us sketch the arc of the Bank of Amsterdam's evolution. Around 1600, debasement caused the bill market in Amsterdam to suffer from poor coinage. The city created the Bank of Amsterdam in 1609 to insulate the bill market from the repressive practices of the mints. Over time, the Bank learned how to better escape coin ordinances, how to offer a high quality ledger-money, and how not to abuse its privileges. For most of the eighteenth century, the city chose monetary efficiency, and the Bank competed well for international bill business. With war with England in the 1780s, however, the city and its Bank moved towards lending and away from stability. Domestic seigniorage increased, but the change greatly damaged the international demand for the bank guilder. The story came to a swift conclusion in 1795.

\section{Founding}

The City of Amsterdam opened the Bank of Amsterdam in January 1609. The exchange bank was modeled after Venice’s Banco di Rialto (van Dillen 1934: 79). The Venetians had introduced a municipal bank in response to private bank failures. Amsterdam took the idea but used it instead to insulate the bill market from debasement. The debasement problem had its roots in the political structure of the Dutch Republic. The governing body of the Republic, the Staten General, issued mint ordinances that specified the weight, fineness and legal value of Dutch coins. For example, these elements combined to give the 1606 rijksdaalder coin a nominal value

\footnotetext{
${ }^{3}$ The rise of the Amsterdam bill market coincides with the general economic expansion of the Dutch Republic during the Golden Age, and it is difficult to sort out the marginal contribution provided by the Bank of Amsterdam. As has been emphasized by various authors (e.g., Spufford 2006), however, the strength of Amsterdam's institutions allowed it to thrive as a financial center, even after economic growth had largely ceased.
} 
(called the mint equivalent) of 22.5 guilders per mark of pure silver (Polak 1998b: 70). ${ }^{4}$ The national government, however, did not have a mint. Instead, each province, and a few cities, had one, so the Netherlands had multiple producers of the same coin (Polak 1998a: 16-7). The mints competed for customers through the quality of the coins produced and the amount of fees charged. One would expect high-quality coins produced at a low cost would attract the most business.

Instead, mints had incentives to debase, and those incentives required the complicity of mint customers. Why? A mint could secretly issue debased coins, but such behavior could not go on long before detection by money changers, and a subsequent loss of business (Rolnick, Velde, and Weber 2006). But Dutch debasement continued through the Revolt years and in subsequent periods of war. How? Mints shared the profits of debasement with customers like money changers and others with specialist knowledge of coins. Mints did this by giving out more coins with less metal per coin. For example, ordinances specified that 9.5 rijksdaalders contain a mark of pure silver (Polak 1998b: 70); in modern units, the "guilder” embodied in a rijksdaalder contained about 11 grams of silver. By reducing the silver content of each coin by a small amount (generally 2 percent or less), a mint could produce a few more coins from a given weight of silver. ${ }^{5}$ The legal value of a coin did not change with the silver content, so the mint could share this extra purchasing power with its customers. Those intermediaries could then pass the debased coins onto the unaware (Munro 2012). Eventually, the light coins would be used to settle debts, for creditors often had to accept the coins at their legal value, whether aware of debasement or not (Quinn and Roberds 2009a). A mint could still profit even if it returned all the metal from de-

\footnotetext{
${ }^{4}$ The guilder was a "ghost money" (Sargent and Velde 2002: 126), a coin that no longer circulated but continued to serve as a unit of account.

${ }^{5}$ This was possible given contemporary technology for metal assay. Detection of silver fineness by touchstone was accurate to 3 percent at best (Gandal and Sussman 1997: 444). Weight could be accurately assayed only with large amounts of coins.
} 
basement to its customers, for debasement brought increased volume, so a mint could collect standard fees more frequently (Quinn and Roberds 2009b).

To illustrate how this competition worked in practice, it may be instructive to examine the coin production of two particular provincial mints (of Holland and Utrecht) for the years just before the founding of the Bank of Amsterdam. We rely on assessments of the mints made by Staten officials, for the Republic regularly sent assayers to test mint output and levy fines if coins were too light. The fines, however, went to the controlling authority, so the system discouraged debasement only if the province or city did not want debasement. These records allow us to construct Table 1, the quantity and quality of rijksdaalder production by each mint. Column A translates the assessed silver contents into guilders per mark pure silver. Holland's coins were found acceptable (less than the maximum allowed tolerance) while Utrecht's coins were found to be debased. Column B reports rijksdaalder production in marks of pure silver. The last column reports the total revenue (brassage and seigniorage) that this volume would generate by assuming that each mint charged customers the ordinance mint price of 22.15 guilders per mark. 


\section{Table 1. Rijksdaalder production at two mints, circa 1607}

Official standard with maximum allowable tolerance

Values observed

In Holland 1606-1607

In Utrecht 1606-1608

Ratio of Utrecht over Holland
(A) Mint equivalent in guilders per mark pure silver

22.614

22.568

22.666

$100.4 \%$
(B)

Annualized production in marks pure silver
(C)

Annualized revenue in guilders

Source: Authors’ calculation from Polak 1998b: 103,130, 185, 195.

The bottom row tells the story. Utrecht produced slightly debased coin (4 tenths of one percent lighter than Holland), yet Utrecht had over 6 times Holland's production and 8 times Holland's revenue. Utrecht offered less silver per coin, yet customers clearly preferred Utrecht. We suspect, but cannot prove, that Utrecht attracted that business by sharing some the debasement revenue. In this way, Utrecht customers got more guilders per mark than Holland customers.

A consequence of widespread, modest debasement was that debtors paid creditors with debased coin. That was bad for the bills of exchange market because international merchants had choices regarding where to send bills. Cities competed to provide the best environment for the settlement of bills, and efficient settlement relied on a number of factors including a reliable unit of account. Debasement meant that the guilder delivered less silver than decreed and that the amount of lightness was unclear. Dutch debasement was not so severe that the bill market was imperiled. If debasement was so extreme as to be easily detected, then creditors might attempt legal re- 
sistance. Instead, debasement was a nettlesome problem made worse because mints outside Holland were creating it.

With the political structure of the Republic unable to impose mint discipline, Amsterdam took action, and the loose political structure of the Dutch Republic that allowed mints to debase also allowed Amsterdam to create a municipal bank. The Bank of Amsterdam did not challenge existing concepts of money or the sovereignty of other political entities. Indeed, the Bank defended coinage standards. Located in the old city hall, the exchange bank took coin deposits and pledged to deliver ordinance-quality coins at withdrawal. The bank would take any loss from light coins. To prevent arbitrage --- people depositing light coin and immediately withdrawing full coin --- the Bank only accepted larger Dutch trade coins at ordinance values. All other coins, including foreign coins, were valued by metal content. Moreover, the Bank charged a withdrawal fee of 1.5 to 2 percent, and the Bank decided what coin to offer at withdrawal. It charged an additional "money changing” fee for the withdrawal of other coins (van Dillen 1964a: 348; Quinn and Roberds 2010: Table 2).

The restrictions and fees eliminated arbitrage profits. They also made the Bank of Amsterdam an expensive place to put coin for short periods and a cheap place to put coins for long periods. A 2 percent fee on a one month deposit makes for an annualized interest rate of over 24 percent! In contrast, coins deposited in perpetuity never paid a fee, so the Bank saw limited metal flows in or out. Instead, people circulated balances between accounts, also at no fee. The Bank did not issue notes, so bank guilder circulation was strictly between accounts. The transacting parties 
could go to the Bank together, but the common process was for a payor, or his proxy, to attend the Bank and push money to the payee's account. ${ }^{6}$

The success of the enterprise, however, required people to deposit coin, and it is not obvious that the Bank of Amsterdam offered better terms than the private cashiers who supplied similar payment services. So, true to the Mahagonny theories, in 1609 the city also banned cashiers and required that all bills of exchange above 600 guilders be settled on the Bank's ledgers. This legal monopoly was however never perfectly enforced, but it did create demand for deposits, for the Bank’s metal stock grew from zero to 925,562 guilders during its first year and to 1,403,675 during its second year (Van Dillen 1934: 117). ${ }^{7}$ The city soon (1621) re-allowed cashiers, but the Bank’s leaky monopoly on bill settlement endured.

Given the expense of transacting at the Bank, we believe that the chief reason the bill market came to prefer the Bank was in order to protect creditors against debasement. In the process, the Bank assured international creditors where, how and with what bills would be settled. The Peter Pan effect could work to keep costs down: if the Bank was sufficiently popular, coins were rarely withdrawn and withdrawal fees were not incurred. Finally, the whole was designed to be stable. The Bank was not designed to lend, so substantial reserves and the implicit backing of the city protected the collateral.

\footnotetext{
${ }^{6}$ The early ledgers of the Bank have unfortunately been lost, so we have no direct proof that such "giro" payments immediately became the norm in Amsterdam. However contemporaneous ledgers from a similar exchange bank in Middelburg were examined by van Dillen (1964a: 350) who found extensive use of giro settlement.

${ }^{7}$ To give some perspective on these figures, consider that a contemporary daily wage for an unskilled laborer would have been approximately one guilder (De Vries and Van der Woude 1997: Table 12.5). A typical bill of exchange would have been for one to two thousand guilders.
} 


\section{Policy and Innovation}

The Bank of Amsterdam supplied a ledger-money that it could destabilize through lending to gain rents. The Bank's early decades were spent exploring this trade-off. Within its first decade, the Bank lent to the young Dutch East India Company, the great government-sponsored enterprise of the age. The Bank also lent to the City of Amsterdam, the Amsterdam Lending Bank, and to select individuals like mint masters (Uittenbogaard 2009: 124). Lending paid interest to the Bank and assisted politically important institutions, but it also made the Bank vulnerable to runs. After its first two decades, the Bank's outstanding loans of 2.1 million guilders exceeded the bank's metal stock of 1.6 million guilders (van Dillen 1934: 117).

The Bank started with a policy analogous to modest debasement, and then policy shifted towards stable money. We do not know why, but the Bank began to reduce its lending. From 1630 to 1650 deposits more than doubled as lending shrank by half. Aggressive lending, defined as loans exceeding metal stock, did not return until the Fourth Anglo-Dutch War (1780-4). Figure 1 shows the change using the Bank's overall balances and metal stock at the end of each fiscal year (mid-January). The gap between balances (black) and metal (grey) represents lending in the 1620s. The reverse, metal exceeding balances, shows the bank's retained earnings exceeding what small amount the Bank was lending in the 1640s. 
Figure 1. Bank of Amsterdam 1610 to 1650

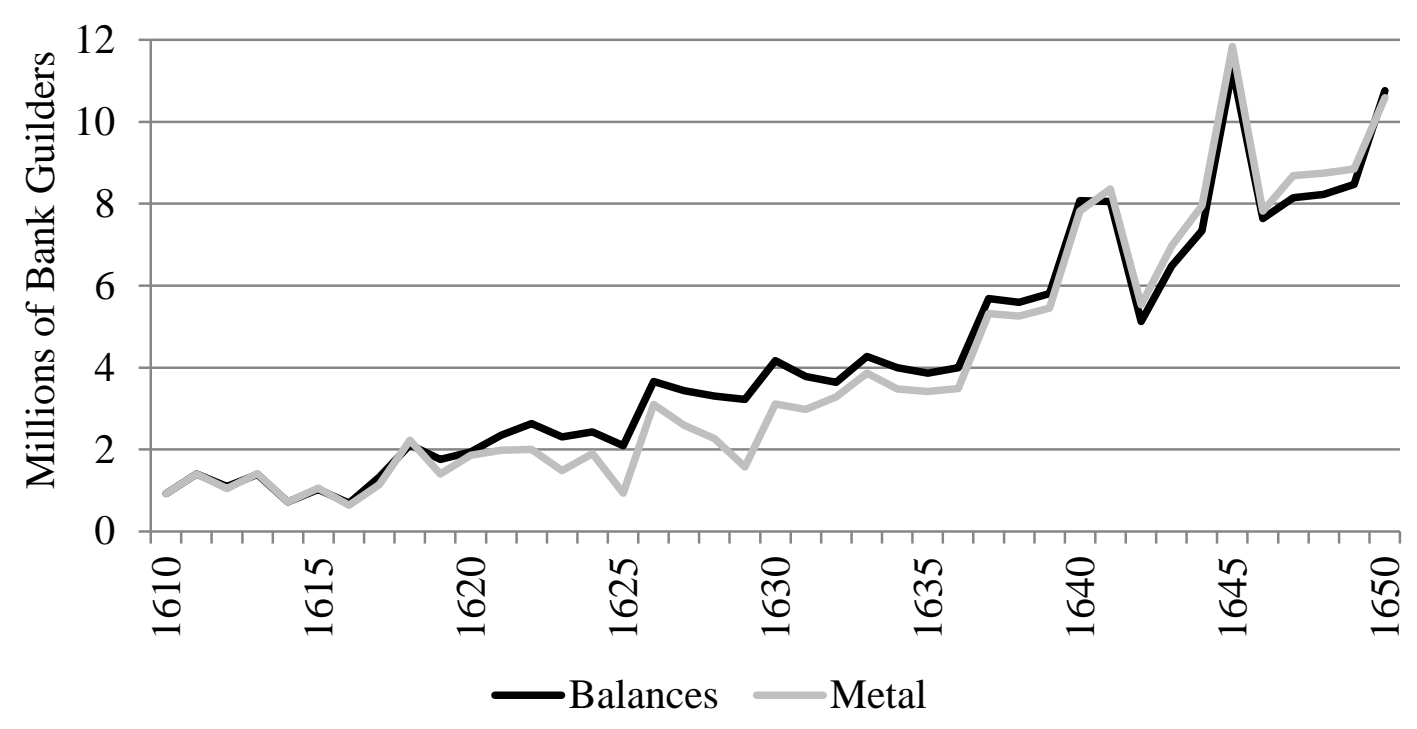

Source: van Dillen 1934: 117-23.

While the Bank of Amsterdam settled into a long-term policy of monetary stability, many mints did not. The ongoing Eighty Years War (1568-1648) strained fiscal resources, and debasement was a way for provinces and cities to supplement their revenues. Of particular importance was a mint located outside the Republic: the Antwerp mint in the Spanish Netherlands. In 1612, Antwerp began production of a new coin, the patagon, that had ordinance-defined content four percent lighter than the Republic's rijksdaalder, yet the patagon had the same ordinance value of 2.4 guilders (van Cauwenberghe and Verachten 2012). While that value had legal standing only in the Spanish Netherlands, the coin was designed to, and did, successfully compete in the north where people used it as a trade coin. Antwerp also engaged in mild debasement. For example, the 1612 run of patagons in Antwerp were fined 0.5 percent of its value for lightness. ${ }^{8}$

\footnotetext{
${ }^{8}$ Calculated by the authors using the van Cauwenberghe and Verachten (2012) data set.
} 
Because the patagon circulated in the Republic at 2.4 guilders, the rijksdaalder (containing more silver) took a higher market price. The Republic recognized this fact by increasing the rijksdaalder's ordinance value to 2.5 guilders in 1619 . When that did not stymie the invader, the Republic tried direct discouragement by assigning the patagon a diminished value of 2.35 guilders in 1622. People apparently kept using 2.4 , and the patagon became the standard trade coin in the Republic (de Vries and van de Woude 1997: 86).

This odd situation made the Bank of Amsterdam a bulwark of an old standard. The Bank had to accept patagons at 2.35 guilders each, but it still delivered Republic coins at their ordinance values, such as the rijksdaalder at 2.5 guilders each. That meant that depositors were protected from Antwerp debasement, and it meant that people gained no arbitrage return from depositing patagons and withdrawing rijksdaalders. In the process, the Bank's monetary function shifted from defending the standard of circulating coins to maintaining standards (the rijksdaalder) abandoned outside the bank (the patagon). The result put the Bank in the position of backing accounts with high quality collateral that had little role outside the Bank, but even that became unsustainable as circumstances forced the Bank of Amsterdam to begin inventing a new, and surprisingly modern money.

In acknowledgement of circulating reality, the Republic increased the legal value of patagons to 2.5 guilders in 1638 . The result for the Bank, however, was arbitrage. People could now make an immediate return (4 percent less fees) by depositing patagons and withdrawing rijksdaalders. The Bank soon ran out of rijksdaalders, and, to save the enterprise, the Bank unilaterally switched to issuing out patagons at withdrawal. The change ended the arbitrage run, but it also broke covenant, for all depositors had their collateral reduced by 4 percent. The Bank had abandoned the Republic's coinage. Then, grasping for a way to repair collateral values, the Bank 
stumbled into a unique solution of pricing patagons at 2.4 guilders instead of 2.5 (van Dillen: 362). At that price, a withdrawal received 4 percent more coins to counteract the 4 percent less silver per coin. In doing this, the city and its Bank broke from Republic ordinances that priced the patagon at 2.5 .

Today, this practice of discounting ("haircutting”) collateral is standard procedure at virtually every central bank. But for the time it was an act of political defiance, and one with an unanticipated consequence, for a patagon in Amsterdam now had two prices: 2.4 guilders at the Bank and 2.5 guilders outside the Bank. Two prices meant that the Bank now had a distinct unit of account that came to be called the bank guilder. For years prior, bank money had represented a rijksdaalder while cashier accounts represented a patagon. Now, both the Bank and cashiers used the same coin to back different amounts of guilders: 2.5 current guilders versus 2.4 bank guilders.

A distinct unit of account was an unintended, but helpful innovation, for now a market developed to price the exchange rate between bank and current guilders (Quinn and Roberds 2007). That exchange rate was called the agio, and it was measured as the ratio of current guilders per bank guilder. For example, a patagon had a bank agio at deposit of 1.04 (2.5 current/2.4 bank). Leaving the bank, the same coin had a bank agio of around 1.025 (1.04 less a typical 1.5 percent withdrawal fee). Cashiers learned to trade bank guilders for coins at a market agio usually within that spread. For example, a cashier could buy bank guilders at 1.03 by having the buyer transfer bank guilders to the cashier's account (no Bank fee). In return, the cashier would give the seller coins at cashier’s shop outside the Bank (again, no Bank fee). Both sides got a better price than using the Bank's deposit/withdrawal window. 
The emergence of a market agio had a few consequences for the Bank. People had even less reason to move coins in or out of the Bank because it was cheaper to get the same result using the secondary market. This reduced Bank revenue but it made bank money more liquid (easier to convert). So the agio market moved the Bank's policies away from rents and towards monetary efficiency.

The dual unit of account arrangement was so thoroughly adopted that the system endured even when the Republic finally purged the patagon. In 1659, the Republic introduced two new silver coins, the silver dukaat and the silver rijder, and each was assigned a legal tender value in bank guilders and current guilders. ${ }^{9}$

Did the agio help stabilize bank money? Based on our examination of ledgers starting in 1666, the Bank did not try to manipulate or manage the agio. Instead, the Bank let the agio float, so high agios attracted new deposits while low agios encouraged withdrawals. This specie-flow mechanism kept the agio anchored around 4 percent, but the process caused the stock of bank money to decline over the years because low agios were more frequent that high agios.

The Bank responded to this long-term decline by occasionally engaging in another, surprisingly modern type of policy—expanding the stock of Bank money by buying large amounts of silver bullion (as much as 10 metric tons in a single month; see Quinn and Roberds 2010: 21). The Bank waited to execute open market purchases until the agio was particularly strong, because bank guilders would buy more silver than usual. The Bank did occasionally sell some silver, but the net effect was to counteract the decline in deposits. The stock of bank guilders stayed between 6 and 8 million guilders from 1659 to 1683 .

\footnotetext{
${ }^{9}$ Confusingly, the new dukaat became known as a rijksdaalder, the new rijder as a ducaton, and the old rijksdaalder as a bank rijksdaalder. See for example the Bank inventory of 1711 (AMA 5077/1355, folio 1-2).
} 
This period was punctuated by the Crisis of 1672 . The crisis proved the Bank resilient, for both the province of Holland and the Dutch East India Company suspended debt payments while the Bank of Amsterdam maintained convertibility. Still, the shaken Bank raised fees to discourage withdrawals, and those fees also discouraged deposits (Quinn and Roberds 2010: 9). By the mid-1670s, the Bank supplied a well-backed money with deep secondary liquidity, but it suffered from high primary costs, a wide-ranging agio, and little revenue generation. Figure 2 shows the stagnation of the Bank's balances in this era.

Figure 2. Bank of Amsterdam 1650 to 1680

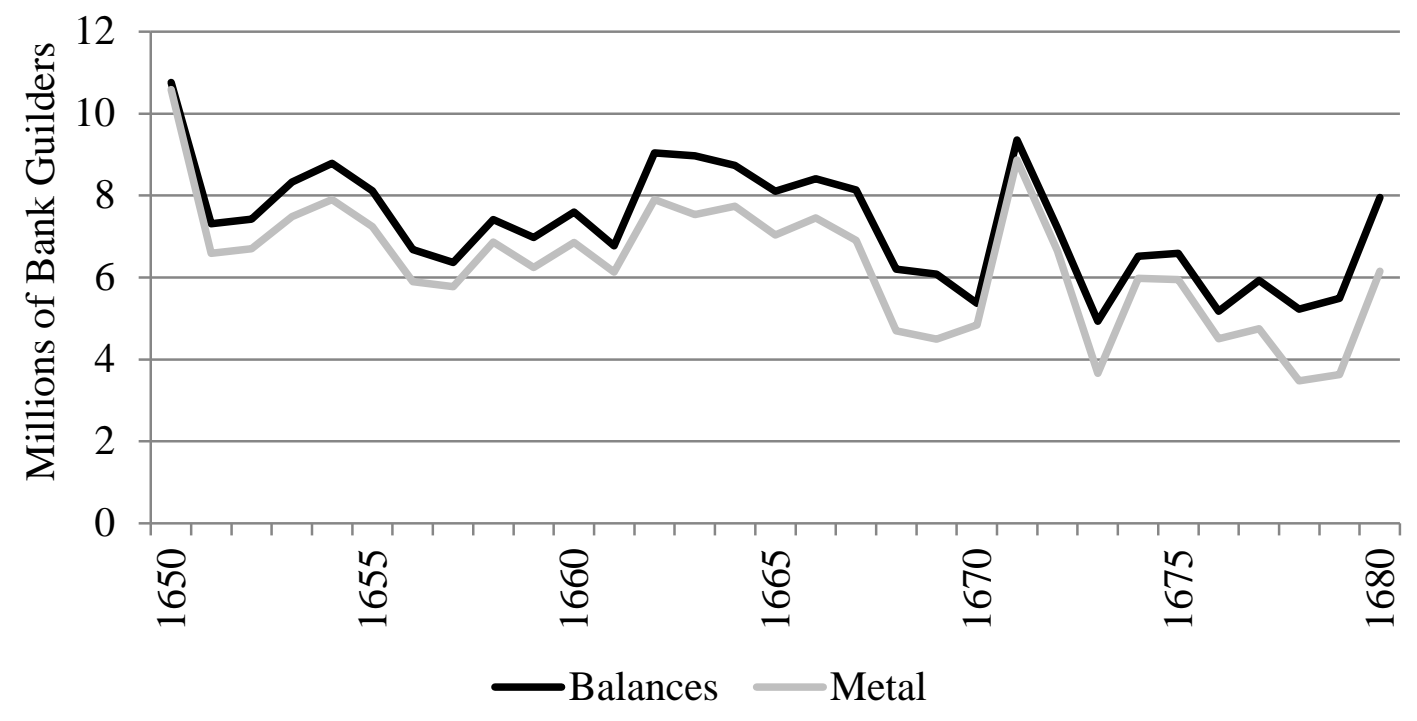

Source: van Dillen 1934: 117-23.

In 1676, Amsterdam merchant Johannes Phoonsen published an essay arguing how the Bank could rectify these shortcomings while maintaining most of its virtues (van Dillen 1921). In 1683, the Bank of Amsterdam followed some of Phoonsen's ideas, and introduced three related changes. 
- People could now withdraw the same coin that they had previously deposited. To track this system of specific collateral, the Bank began issuing negotiable receipts at deposit.

- A receipt charged a much lower fee to remove coin than traditional withdrawal: $1 / 4$ percent for most silver coins and $1 / 2$ percent for gold coins. The traditional fee was 1 to 2 percent.

- The Bank ended the right of traditional withdrawal, meaning people could no longer demand coin because they had an account balance. Instead, people needed an account balance to pay for the coin and a receipt granting the right to buy the coin.

The last change effectively made the bank guilder a fiat medium of exchange. This innovation made the bank guilder similar to money in a modern central bank account in that both can be transferred but neither is inherently convertible. Extending the analogy, the receipt behaved like a modern repurchase agreement. Like a repo, people delivered coin as collateral to the Bank, and they received a loan of credit to their account. They were also given a receipt, i.e., an option to repurchase the coin. ${ }^{10}$ When people repurchased the coin, they also paid a fee, so the fee acted as a 6 month interest payment. If people did not repurchase the coin, then they kept the bank guilders and the Bank kept the coin. The analogy to modern central bank repo, however, has caveats. The Bank of Amsterdam did not manipulate the interest rate (the fee structure) or the quantity contracted (unlimited). Also, a receipt could be rolled over in 6 month increments by paying only the fee, and the receipt could be transferred. With transfer, receipts developed their own resale market.

More people used the Bank because it was now cheaper to later leave the Bank. Flows into and flows out of the Bank sped up, and now people paid a fee each half-year, whether they removed coins from the Bank or extended the option (Quinn and Roberds 2010: 18). And most receipts

\footnotetext{
${ }^{10}$ By structuring the receipt as an option rather than evidence of a debt, the Bank was able to guarantee its priority as a creditor. This meant that the Bank could offer what were essentially collateralized loans on advantageous terms, i.e., at lower interest rates and lower collateral haircuts than could a private lender (Mees 1838).
} 
were rolled over. The Bank also began to charge a small fee on all intra-bank transfers. From 1674 to 1682 , average annual fee income was 15,615 bank guilders. From 1684 to 1690 , it was 25,401: an increase of 60 percent. ${ }^{11}$ Now the Bank collected fees from people using the Bank instead of just from leaving the Bank.

The net effect of all that flow was a rise in deposits of about 4 million bank guilders in the first decade of the new regime. Figure 3 reports the annual balances for this innovative era. A second surge of deposits came after the end of the Nine Years' War in 1697. Why did more coin want to stay at the Bank than ever before? Low fees made the Bank a cheaper place to park coin, so more transient capital moved in. Easy access to that liquidity (short-term loans) and to that collateral (transferable receipts) deepened the Amsterdam bill market.

${ }^{11}$ Annual fee revenue calculated by subtracting interest revenue from total revenue for each year. All data from AMA 5077/1318-1322. 
Figure 3. Bank of Amsterdam 1610 to 1650

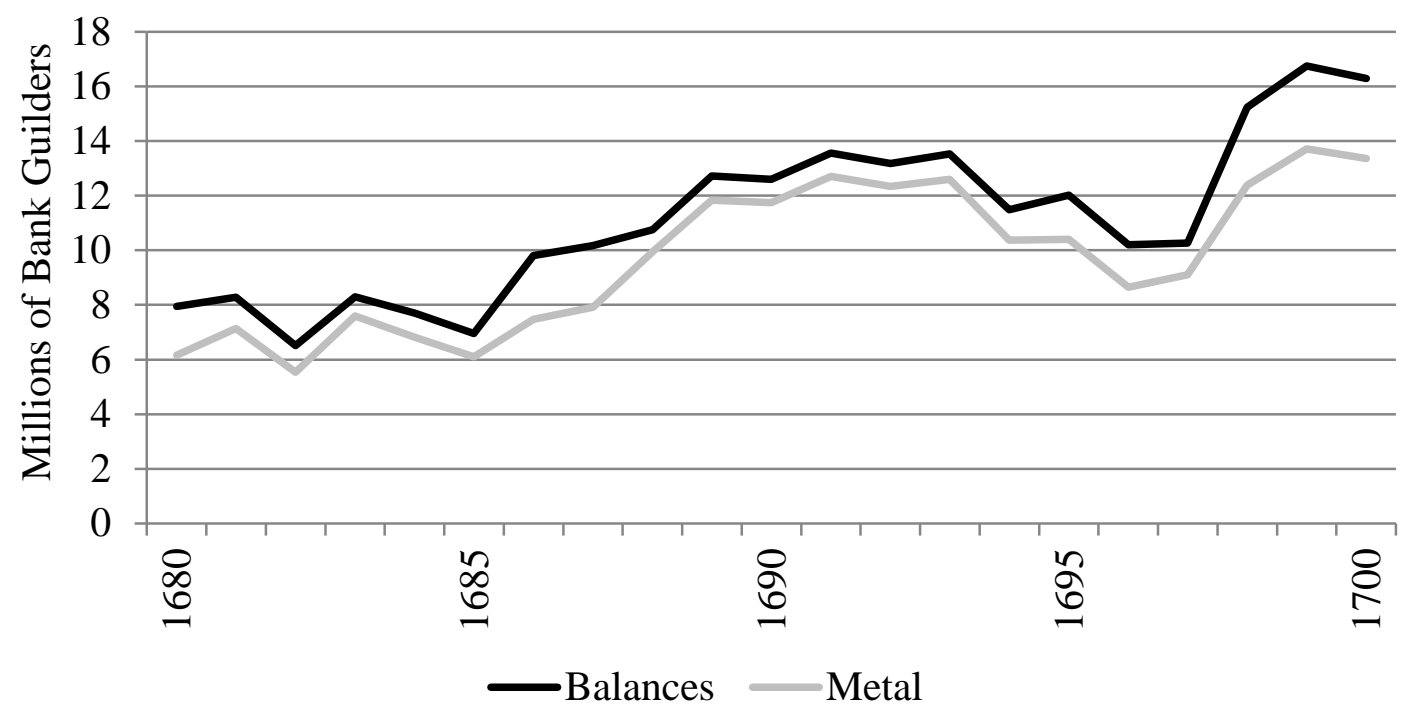

Source: van Dillen 1934: 117-23.

A potential downside was that international "hot" money could leave the Bank as quickly as it came. The new fiat nature of the bank guilder, however, increased the stability of the Bank, for a run could no longer be larger than the stock of outstanding receipts. The Bank could not fail if it kept the receipt-coins in its vaults. Bank guilders unencumbered by a receipt, and there were about 8 million in 1683, were solely vulnerable to the market agio. A declining agio would cost account holders purchasing power, but the Bank itself would not be undone. Changing the threat from the discontinuity of a potential suspension to the continuity of a price decline was a stabilizing innovation.

In terms of political economy, the monetary innovations of 1683 helped Amsterdam become the preferred place for people to operate the bill market. In modern parlance, the bank guilder was winning the competition for the status of international reserve currency. The new fee structure had the Bank making money on this popularity. After 1683, the Bank begins to share its sei- 
gniorage with the City of Amsterdam. At first, the Bank made zero interest 'loans' that the city never repaid (Quinn and Roberds 2010: 26). In the eighteenth century, the city switched to just taking the Bank’s annual profits.

With the introduction of the receipt system, the monetary transformation of Amsterdam (and de facto the Republic) was now complete. The most liquid asset in the economy was no longer coin, but a sort of "virtual banknote" residing in Bank of Amsterdam accounts. The beauty of this scheme lay in its subtlety: to anyone holding balances and a receipt, Bank money corresponded simply to the coin that had been deposited. To those not holding a receipt, coins could be readily purchased in Amsterdam's liquid market. In this sense, the Bank's rather abstract form of money did not directly confront the monetary authority of the Staten, or the primacy of coin. ${ }^{12}$

\section{Hegemony}

In the 1700s, the bank guilder became the leading money for settling bills, and Amsterdam became the hub of the international bill market. Lucien Gillard (2004) calls it the European guilder (le florin européen), and Adam Smith devotes many pages to explaining how the bank guilder works (Smith 1776: 446-55). Bills on Amsterdam were more widely available (in 85 percent of commercial cities) than bills on any other location in Europe (Flandreau et al. 2009). The reforms of 1683 formed the bedrock of the bank guilder's preeminence, but in this section we identify two complementary developments that promoted the hegemony of the bank guilder. The Dutch Republic stabilized the quality of its coin production, and merchant banking made Amsterdam the capital of credit. The former was a political solution that finally solved an old problem while the latter was an economic solution that produced a new problem.

\footnotetext{
${ }^{12}$ A noteworthy contrast is provided by the more direct approach of another contemporary municipal bank, the Bank of Hamburg. Beginning in 1770, the Hamburg institution explicitly defined its accounts as a claim on silver bullion rather than coin, and always stood ready to buy and sell bullion at posted prices (Sieveking 1934: 150).
} 
The introduction of new coins in 1659 did not solve the old problem of multiple mints producing legal tender coins. Provinces, beginning with Zeeland in 1676, began introducing light coins that tried to play patagon to reformed coins of 1659 (Quinn and Roberds 2010: 37-8). By 1688, production of the new arensdaalder and florijn coins outpaced traditional trade coins at the provincial mints (Polak 1998a: 196-7). The province of Holland, however, opposed the trend, and instead promoted a new gulden (guilder) coin to act as the standard for current money. This battle did not affect the collateral at the Bank of Amsterdam, for the Bank took none of the new coins at its receipt window. But the deteriorating quality of circulating coin did push up the agio on bank money. It peaked at 12.5 percent in January 1693 (McCusker 1978: 48).

The coinage battle turned into a political fight as Holland banned the light coins in 1690 and got the Republic to do the same in 1694 (Polak 1998a: 199-200). Some municipal mints were paid to close, and the remaining mints accepted the non-debased gulden coin as the standard. Holland had finally succeeded in ending the mint chaos through political power, and the Republic's silver coins entered a period of enduring stability. That resolution also ended pressure on the Bank's agio from domestic mint standards, so coin stability translated into agio stability.

To see the agio over a very long period, Figure 4 plots a monthly agio from January 1653 to January 1780 . Some eras, like 1700 to 1720 , have few observations, but long-term trends can be discerned with the assistance of a polynomial ( $3^{\text {rd }}$ order) trend line. In particular, the agio increased from its patagon origins until 1694. The eighteenth century was relatively flat. For decades, the agio stayed between 3.5 and 5.5. The notable exceptions are the start of the War of Spanish Succession (1704-13), of which we know little, and the end of the Seven Years War (1757-63), of which we will say more below. 
Figure 4. Monthly Agios, 1653 to 1780

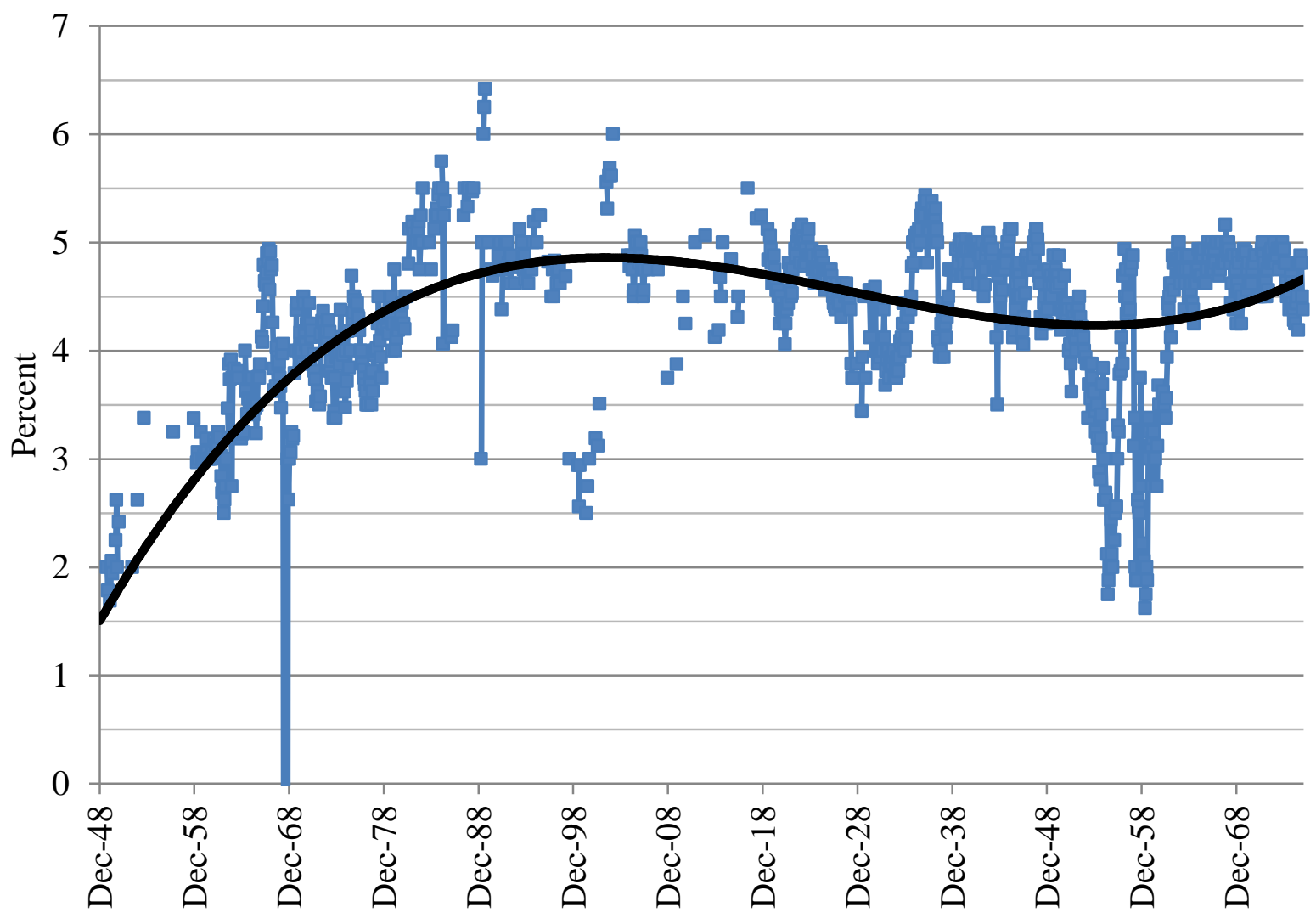

Sources: McCusker 1978, Gillard 2004, AMA 234/290-295.

For the decades following the War of Spanish Succession, Bank balances were also fairly stable.

Figure 5 shows that balances generally ranged around 15 to 20 million bank guilders. 
Figure 4. Bank of Amsterdam 1700 to 1780

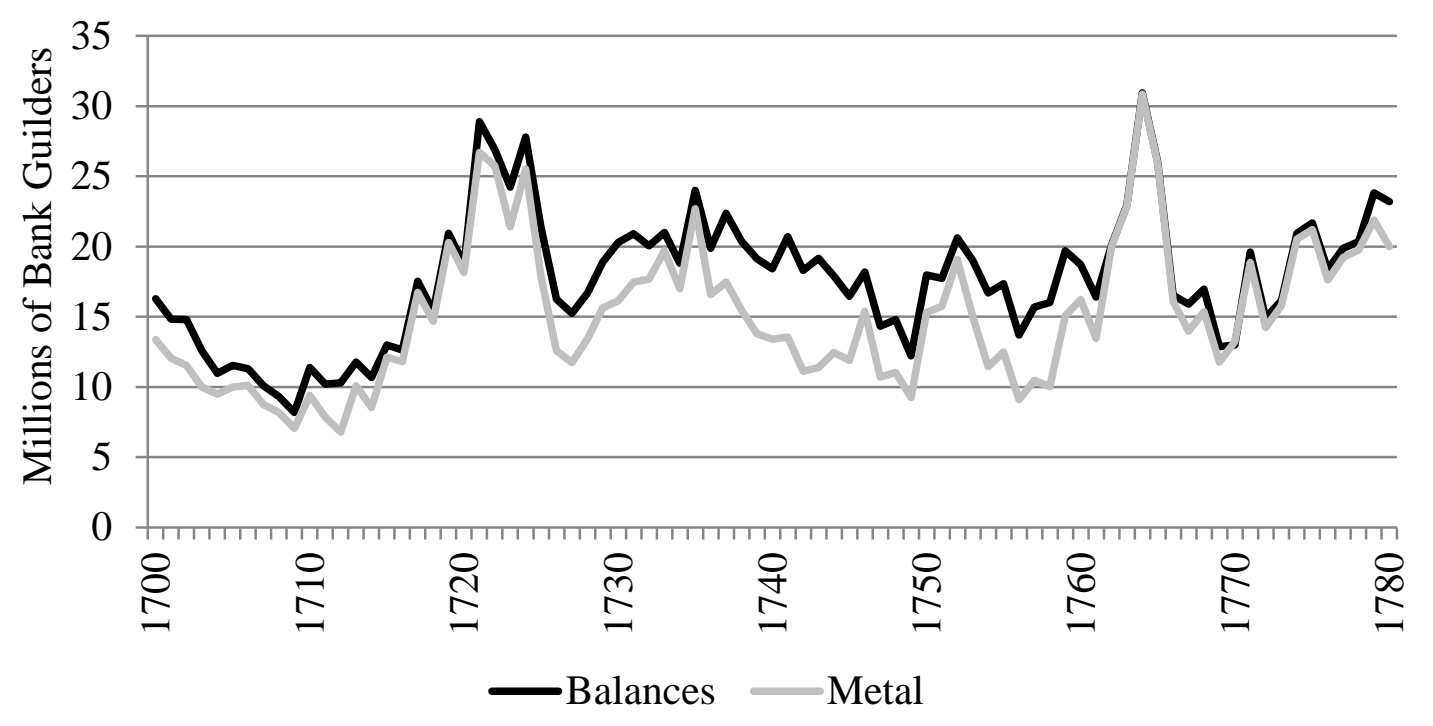

Source: van Dillen 1934: 117-23.

The bank guilder's convenience (see reforms of 1683) and price stability (add reforms of 1694) so deepened the bill market in Amsterdam that large-scale merchant banking could develop. To use bills of exchange, people 1) had to arrange for someone to accept and settle a bill and 2) had to convince creditors that the arrangement would work. The earliest bill networks relied on everyone to return to recurring fairs in order to settle bills (Boyer-Xambeu, Deleplace, and Gillard 1994: 66-103). Later systems had bankers arrange overseas agents to accept bills, so creditors could trust the bill would settle (Neal and Quinn 2001). The merchant bankers of Amsterdam reversed the polarity. Customers in Hamburg, London or other cities drew bills to bankers in Amsterdam, and creditors trusted that Dutch bankers would accept and settle bills. Merchant banks attracted bills to Amsterdam, and such flows further deepened the city's money market.

The system relied on the credibility of merchant banks like Andries Pels \& Zoonen and George Clifford \& Zoonen. Both firms had annual turnovers at the Bank of over 5 million bank guilders 
as early as $1719 .{ }^{13}$ The firms Hope \& Co. and Raymond \& Theodor de Smeth reached 5 million during the War of Austrian Succession (1740-8) while still others joined that club during the Seven Years' War (1756-63). Traditional merchant banking relied on what was viewed as a conservative business plan: funding by deposits was eschewed in favor of bills, preferably backed by commodities so that sale of the collateral would pay for the bill.

The Bank of Amsterdam supported the acceptance market with a settlement process that was convenient and final. Moreover, the resulting bank guilders were stable and the gateway to all that the center of the financial world had to offer. Creditors could repatriate the money for a typical return of 2 to 4 percent, could spend bank guilders on nearly any of the world's commodities, or could invest in securities like the Dutch East India Company or British stocks. The merchant banks pulled in credit from all around Europe and then supplied it access to all Amsterdam’s opportunities.

Amsterdam’s credit swelled during the Seven Years War. Balances at the Bank rose from 13.7 million to 22.9 million (see Figure 4). Financial flows focused on Holland as a neutral power, and the traditional merchant banks took advantage to fund the gamut from commerce and to sovereign borrowing. The boom also supported the expansion of banks willing to use more financial leverage. Instead of using capital, banks like de Smeth, Charles \& Theophilus Cazenove, and Gebroeders de Neufville aggressively borrowed money in order to pay creditors. Instead of requiring collateral, they were willing to extend unsecured credit. By the first half of 1763, the conservative merchant banking firm of Pels was paying out 70 percent of its balance at the Bank of Amsterdam each week, meaning that Pels had to replenish its account every ten days or so (Quinn and Roberds 2012). At the other extreme, the bank Cazenove paid out over 400 percent

\footnotetext{
${ }^{13}$ These figures were collected by Simon Hart (AMA 883/405).
} 
of its balances each week, so Cazenove had to replenish its balances every day or two. Cazenove was constantly selling new bills to pay for bills it had already accepted.

All this lending and leverage came to a sudden stop in August 1763 (de Jong-Keesing 1939). The shocking failure of a large merchant bank (de Neufville) caused the market to contract its lending to banks, banks to stop accepting bills, and creditors to stop lending on the security of bills. The crisis spread out with particular disruption to Hamburg, Berlin, the Baltic and other areas highly dependent of the Amsterdam credit market (Schnabel and Shin 2004).

None of this was the Bank of Amsterdam's fault, yet the crisis thrust the Bank into a new policy role, that of lender of last resort. The crisis destabilized demand for bank money and, consequently, the agio (de Jong-Keesing 1939). Moreover, the crisis blurred the traditional policy trade-off between stability and lending because last-resort lending stabilizes bank money by assisting banks, yet destabilizes bank money by moving credit risk onto the books of the central bank. At one extreme, the city could have used the Bank to bail out de Neufville. People did so petition, but no bailout was forthcoming; Amsterdam decided that de Neufville was not too big to fail. At the other extreme, the Bank could have done nothing new, so emergency lending would have been limited to coin collateral. Quinn and Roberds (2012) find that all bankers used this traditional facility, but a few additional banks needed more to prevent failure. In the end, the Bank of Amsterdam chose a middle course, introducing a new lending window that accepted silver bullion. While the amount of borrowing through this new facility was not very large, it made a crucial difference for banks very close to failing.

In Amsterdam, no merchant bank beyond de Neufville failed, so the Bank's policies were a local success. Outside Amsterdam, however, ruin was widespread. The bill market in Hamburg shut 
down for months, and Prussia suspended commercial debts. The result was that the markets that feed demand to Amsterdam shrank and began relying more on London (Carlos and Neal 2011). The weakening of Amsterdam relative to London continued after another major panic in 1772-3. While the Bank of Amsterdam was solid, Europe was learning that the Dutch banking system was not. The hegemony of the bank guilder slipped.

\section{Decline and Collapse}

The decline of the Bank of Amsterdam accelerated with the Fourth Anglo-Dutch War (1780-4). The British blockade of Holland and the capture of many Asian colonies put tremendous pressure on the Dutch East India Company. The City of Amsterdam responded by shifting Bank policy towards substantial lending to the distressed company. Loans were also extended to the city, to provincial governments, and to private parties through a new lending facility (Van Dillen 1964c). The cost was a deterioration of the Bank’s balance sheet that contributed to a rapid decline in demand for bank guilders. As Figure 5 shows, the metallic stock of the bank dropped from 20 million in 1780 to 6 million in 1784. Balances remained stable only because the Bank was lending vast amounts to the company. 
Figure 5. Bank of Amsterdam 1780 to 1795

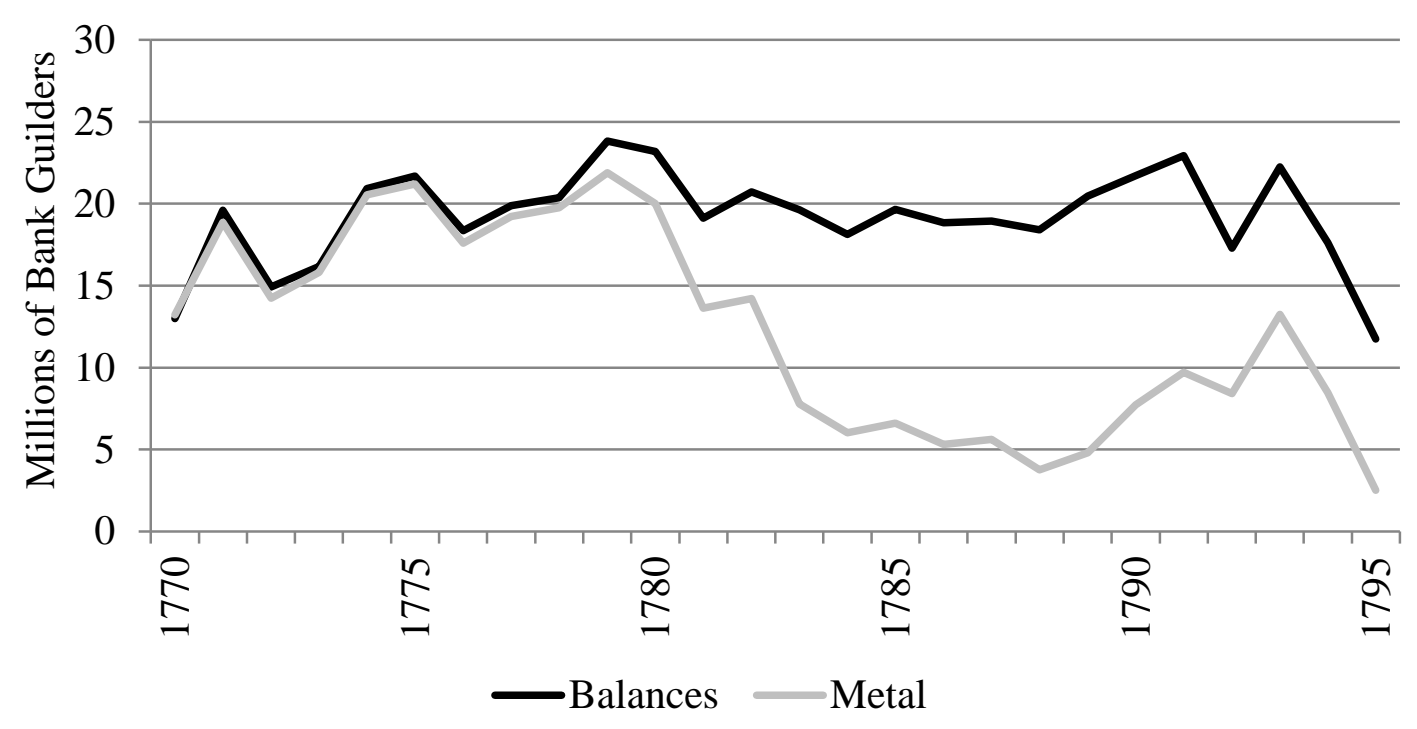

Source: van Dillen 1934: 117-23.

The French Revolution at first caused a revival of the Bank as money sought a safe haven, but Amsterdam proved no lasting refuge. The agio ran negative starting in August 1794, and money that could escape did before the French army arrived in the winter of 1794-5. The Bank of Amsterdam was finally closed in 1819, having been superseded by the Bank of the Netherlands (De Nederlandsche Bank) in 1814 (Van Dillen 1964c).

\section{Conclusion}

Amsterdam created its Bank in response to a destabilizing version of monetary competition. The initial design of the Bank was fairly unimaginative and it was only partly successful at discouraging debasement. Through a series of largely improvised policies, however, the bank guilder developed into an almost unbeatable competitor in the international market for settlement. Such 
was the depth of Amsterdam's innovations that it was not until the end of the eighteenth century that rival Continental centers began to catch up.

The success of the Bank of Amsterdam over many decades followed from primarily the city of Amsterdam's ability and willingness to not unduly exploit the Bank. The sharp fall of the bank guilder in the 1780s highlights the importance of the previous era of forbearance. The "waxen wings" of the 1683 receipt system would carry the Bank to great heights, if in the end it journeyed too close to the sun.

\section{References}

\section{ARCHIVES}

Amsterdam Municipal Archives (Stadsarchief Amsterdam): AMA

\section{LITERATURE}

Boyer-Xambeu, Marie-Therese, Ghislain Deleplace and Lucien Gillard. 1994. Private Money and Public Currencies. M.E. Sharpe, New York.

Carlos, Ann and Larry Neal. 2011. "Amsterdam and London as Financial Centers in the Eighteenth Century.” Financial History Review 18(1): 21-46.

Dehing, Pit, and Marjolein 't Hart. 1997. "Linking the fortunes, currency and banking, 15501800.” In A Financial History of the Netherlands, ed. Marjolein ‘t Hart, Joost Jonker and Jan Luiten van Zanden, 37-63. Cambridge University Press, Cambridge.

De Jong-Keesing, Elisabeth Emmy. 1939. De Economische Crisis van 1763 te Amsterdam. N.V. Intern. Uitgevers en h. Mij, Amsterdam.

De Vries, Jan, and Ad van der Woude. 1997. The First Modern Economy, Success, Failure and Perseverance of the Dutch Economy, 1500-1815. Cambridge University Press, Cambridge. 
Flandreau, Marc, Chritophe Galimard, Clemens Jobst and Pilar Nogues-Marco. 2009. "Monetary Geography before the Industrial Revolution.” Cambridge Journal of Regions, Economy and Society 2:149-171.

Gandal, Neil and Nathan Sussman. 1997. "Asymmetric Information and Commodity Money: Tickling the Tolerance in Medieval France.” Journal of Money, Credit, and Banking 19(4): 440-56.

Gillard, Lucien. 2004. La banque d'Amsterdam et le florin européen au temps de la République neerlandaise, 1610-1820. L'École des hautes études en sciences sociales, Paris.

Kahn, Charles M., and William Roberds. 2009. "Why pay? An introduction to the economics of payments?” Journal of Financial Intermediation 18(1): 1-23.

McCusker, John J. 1978. Money and Exchange in Europe and America, 1600-1775: A Handbook. University of North Carolina Press, Chapel Hill.

Mees, Willem C. 1838. Proeve eener Geschiedenis van het Bankwezen in Nederland geduerende den Tijd der Republiek. W. Messcuert, Rotterdam.

Munro, John H. 2012. "The Technology and Economics of Coinage Debasement in Medieval and Early Modern Europe: with Special Reference to the Low Countries and England.” Working Paper 456, University of Toronto, Department of Economics.

Neal, Larry. 2000. "How It All Began: The Monetary and Financial Architecture of Europe During the First Global Capital Markets, 1648-1815.” Financial History Review, 7: 117-140.

Neal, Larry and Stephen Quinn. 2001. "Networks of Information, Markets, and Institutions in the rise of London as a Financial Centre.” Financial History Review 8(1): 7-26.

Polak, Menno. 1998a. Historiografie en Economie van de 'Muntchaos', Deel I. NEHA, Amsterdam.

Polak, Menno. 1998b. Historiografie en Economie van de 'Muntchaos', Deel II: Bijlagen. NEHA, Amsterdam.

Quinn, Stephen and William Roberds. 2007. "The Bank of Amsterdam and the Leap to Central Bank Money.” American Economic Review Papers and Proceedings 97: 262-5.

Quinn, Stephen and William Roberds. 2009a. "An Economic Explanation of the Early Bank of Amsterdam, Debasement, Bills of Exchange and the Emergence of the First Central Bank." In The Evolution of Financial Institutions from the Seventeenth to the TwentiethFirst Century (2009), ed. Jeremy Atack and Larry Neal, 32-70. Cambridge University Press. 
Quinn, Stephen and William Roberds. 2009b. "Coinage, central bank money and the Bank of Amsterdam.” In The Bank of Amsterdam: on the Origins of Central Banking, ed. Marius van Nieuwkerk: 92-107. Sonsbeek Publishers, Amsterdam.

Quinn, Stephen and William Roberds. 2010. "How Amsterdam got Fiat Money.” Federal Reserve Bank of Atlanta Working Paper 2010-17.

Quinn, Stephen and William Roberds. 2012. "Responding to a Shadow Banking Crisis: the Lessons of 1763.” Federal Reserve Bank of Atlanta Working Paper 2012-8.

Rolnick, Arthur; François Velde, and Warren E. Weber. 1996. "The Debasement Puzzle: An Essay on Medieval Monetary History.” Journal of Economic History 56(4): 789-808.

Sargent, Thomas J. and François Velde, 2002. The Big Problem of Small Change. Princeton University Press: Princeton.

Schnabel, Isabel and Hyun Song Shin. 2004. "Liquidity and Contagion: The Crisis of 1763.” Journal of the European Economic Association 2(6): 929-968.

Sieveking, Heinrich. 1934. “Die Hamburger Bank.” In History of the Principal Public Banks, ed. Johannes Gerard van Dillen, 125-160. Martinus Nijhoff, The Hague.

Spufford, Peter. 2006. "From Antwerp and Amsterdam to London: the Decline of Financial Centres in Europe.” De Economist 154: 143-175.

Smith, Adam. 1776 [Modern Library Edition 1937]. The Wealth of Nations. Modern Library, New York.

't Hart, Marjolein, 2009. “Corporate Governance.” In The Bank of Amsterdam: on the Origins of Central Banking, ed. Marius van Nieuwkerk: 144-155. Sonsbeek Publishers, Amsterdam.

Uittenbogaard, Roland. 2009. "Lending by the Bank of Amsterdam (1609-1802).” In The Bank of Amsterdam: on the Origins of Central Banking, ed. Marius van Nieuwkerk: 120-131. Sonsbeek Publishers, Amsterdam.

Van Cauwenberghe, Eddy and Lucie Verachten. 2012. "Dataset monetaire geschiedenis van de Zuidelijke Nederlanden, 1493-1789," at Geldmuseum, museum over geld en geldcultuur in Utrecht (geldmuseum.nl/museum).

Van Dillen, Johannes Gerard. 1921. "Een Boek van Phoonsen over de Amsterdamsche Wisselbank.” Economisch-historish jaarboek 7: 1-146.

Van Dillen, Johannes Gerard. 1925. Bronnen Tot de Geschiedenis Der Wisselbanken. Martinus Nijhoff, The Hague. 
Van Dillen, Johannes Gerard. 1934. “The Bank of Amsterdam.” In History of the Principal Public Banks, ed. Johannes Gerard van Dillen, 79-124. Martinus Nijhoff, The Hague.

Van Dillen Johannes Gerard. 1964a. “Oprichting en Functie der Amsterdamse Wisselbank in de zeventiende Eeuw 1609-1686,” in J.G. van Dillen, ed. Mensen en Achtergronden, Studies uitgegeven ter gelegenheid van de tachtigste jaardag van de schrijver. J.B. Wolters, Groningen.

Van Dillen Johannes Gerard. 1964b. “Bloeitijd der Amsterdamse Wisselbank 1687-1781,” in J.G. van Dillen, ed. Mensen en Achtergronden, Studies uitgegeven ter gelegenheid van de tachtigste jaardag van de schrijver. J.B. Wolters, Groningen.

Van Dillen J.G., 1964c, “Ondergang van de Amsterdamse Wisselbank, 1782-1820,” in J.G. van Dillen, ed. Mensen en Achtergronden, Studies uitgegeven ter gelegenheid van de tachtigste jaardag van de schrijver. J.B. Wolters, Groningen.

Van Nieuwkerk, Marius (ed.), 2009. The Bank of Amsterdam: on the Origins of Central Banking. Sonsbeek Publishers, Amsterdam.

Van Zanden, Jan Luiten, 2004. "The prices of the most important consumer goods, and indices of wages and the cost of living in the western part of the Netherlands, 1450-1800.” Accessed online at www.iisg.nl/hpw/data.php\#netherlands.

Willemsen, René. 2009. “The Activities of the Bank of Amsterdam.” In The Bank of Amsterdam: on the Origins of Central Banking, ed. Marius van Nieuwkerk: 78-91. Sonsbeek Publishers, Amsterdam. 